Arkadiusz Świadek, Katarzyna Szopik-Depczyńska "Business cycle and innovation activity

of industrial enterprises in Poland - Mazowieckie region case",

Journal of International Studies, Vol. 7, No 3, 2014, pp. 90-99. DOI: 10.14254/2071-8330.2014/7-3/8

\title{
Business cycle and innovation activity of industrial enterprises in Poland - Mazowieckie region case
}

\author{
Arkadiusz Świadek \\ University of Zielona Góra \\ Poland \\ e-mail:a.swiadek@wez.uz.zgora.pl \\ Katarzyna Szopik-Depczyńska \\ University of Szczecin \\ Poland \\ e-mail:kasiasz@wneiz.pl
}

\begin{abstract}
The business cycle is an important factor that can often affect the decisions to undertake or discontinuance of the innovation activity by the industrial enterprise, both in Poland, but also in more developed countries. The primary objective of the study is the attempt to search for directions, as well as the impact of economic conditions on the innovation activity of Polish enterprises in the area of the industrial system of the Mazowieckie province. As a result, it is possible to determine the boundary conditions for the regional network of innovations and its model structure.
\end{abstract}

Keywords: innovation, business cycle, region, industry, Poland

DOI:

JEL Classification: O31, E32, R11, L10, L60

\section{INTRODUCTION}

The problem of business cycle on innovation activity of enterprises is not a new phenomena, but still present, what is confirmed by constantly emerging publications in this field, both on the domestic and foreign market (Dominiak, Churski 2012; Etzkowitz, Leydesdorff 2000; Archibugi at al. 2013; D’Estea at al. 2012). At the enterprise level, literature in economics shows varied impact of the economic slowdown on the dynamics of innovation expenditures. There exists a broadly described dispute in this regard. Traditionally, investments in new technologies should be treated as the anti-cyclical measure for those operating on the enterprise market, because the limitations found in the slowdown period influence the level of their profitability, what generates the imperative of searching for paths to obtain higher productivity. Therefore, according to the concept of „creative destruction” of J. Schumpeter, the crisis creates new perspectives for economic entities (Schumpeter 1939). As the result of this, many of them should seek to reorganize structures and to improve the quality of own innovation activity. The manifestation of this approach should be the personnel of research and development sphere, which in the period of crisis is subject the natural phenomenon of 
"labor hoarding". Then, the most qualified employees are "stored" in the enterprise thanks to the personnel with lower qualifications (Soete 2009). This generates new potential possibilities for the organization development. In turn, lost benefits resulting from the limited demand on labor of directly production employees, should be, in the recession period, the cause for the enterprises for new investments in the area of technology (Stiglitz 1993; Aghion, Saint-Paul 1998; Canton, Uhlig 1999). It is known, after all, that chances for the bankruptcy of enterprises, which do not implement reorganization programs, are higher than in the recession phase (Aghion, G. Saint-Paul 1998).

Despite many logical and common-sense arguments that innovation activity of enterprises should have anti-cyclical character, often in the literature of the subject there appears the view that managers of the enterprises do not consider the innovation activity as different from other types of the conducted activities. This means that the activity should have cyclical character. In the modern economy, generating and implementing new technologies, mostly those fundamental ones, is delayed in the period of recession, and enterprises await the next wave of revival (Shleiffer 1986; Francois, Lloyd-Ellis 2003). In this situation there is no scientific consensus in the area of the validity of the hypothesis of Gerhard Mensch to "accelerate innovation" from 1975, assuming that innovations, especially the radical ones, are more often implemented in the phase of recession as the attempt to search new chances for enterprises willing to survive in the shrinking market (Clark and others 1981).

Business cycle is an important factor that can often affect the decisions to undertake or discontinuance of the innovation activity by the industrial enterprise, both in Poland, but also in more developed countries. The Polish industrial system due to its backward, but improving, character is more often dependent on changes taking place in its proximal and distal environment, and thus in more developed countries. The recent study conducted in the SME manufacturing sector in Spain confirm and at the same time generate equivocal findings in the analysed area, and they are brought down to the following theses (Madrid-Guijarro and others 2013): (1) innovation of small and medium-sized manufacturing enterprises decreases during the economic crisis, (2) types of implemented innovations in Spanish SME change in different economic conditions, and what is extremely interesting, (3) innovation has a beneficial influence on the results of companies both in the economic expansion and recession. The obtained research results show that innovation strategies in the SME sector, despite various phases of the cyclicality, have an important influence on the effectiveness of its functioning and these conditions should be included in the planned and accomplished innovation politics. This provides the rationale to conduct analyses in terms of intensity of engagement in various areas of the innovation activity in terms of changes of the phases of cyclicality.

It can therefore be concluded that the discussion in the studied area was not completed, and the influence of the economic situation on technological changes in enterprises seems to be a phenomena with a more heterogenic nature, than it has been previously observed. The paper presents analyses which aims to expand the current knowledge in this area, especially in the attempt to explain conditions of the functioning of economic systems in the "catching up" type of countries.

The essence of innovation systems are the relations taking place between particular participants of the market creating the network of links. However, this does not mean that innovation systems operate in a vacuum, as they are set in specific economic conditions. Last studies conducted by Joint Research Centre (JRC) in the field of the assessment of the influence of the market conditions on the innovation activity of the economy became a prerequisite to undertake the attempt to assess these phenomena in Poland (JRC 2010). The results of the analyses conducted there still confirm the ambiguity of this phenomena and its impact on the innovation activity. Thus, the question remains current: is the economic recovery, or maybe the recession, the factor stimulating enterprises to accept pro-innovation attitudes? 


\section{THE MAIN GOALS AND RESEARCH CHARACTERISTICS}

The primary objective of the study was, therefore, the attempt to search for directions, as well as the impact of economic conditions on the innovation activity of enterprises in the area of the industrial system of the Mazowieckie province. As a result, it was possible to determine the boundary conditions for the regional network of innovations and its model structure, which would take into account the specificity of this region. The main hipotesis is that business cycle might have a bidirectional impact on the decisions to undertake or discontinuance of the innovation activity by the industrial enterprise.

The effects of original studies presented in this article constitute only a part of conclusions, which were obtained as a result of the conducted multithreaded analyses in the country in the past six years.

The exemplification layer of work was based on the study, in detail exploring the industrial enterprises in the Mazowieckie province. The base to prepare the article was the study conducted in the years 2008-10 on a group of 674 industrial enterprises of the Mazowieckie province.

At the same time the created database of companies is constantly updated, because there are works on the attempt to repeat the studies in next provinces. The basic path of collecting data was the procedure connecting the initial telephone conversation with the sending of the questionnaire form by mail. The supplementary forms were the interviews conducted by the phone or obtaining the filled in questionnaire electronically, or by fax. Improperly filled in questionnaire, depending on the mistake, fundamentally disqualified it from the possibility to participate in next stages of the study. The structure of studied enterprises corresponded in approximation to data presented by the Central Statistical Office. However, unlike the studies conducted in it, there was also included the section of micro enterprises, what is an incidental phenomenon in the scale of our country, trying to present holistically the way of functioning of the national industrial system in Poland.

\section{METHODOLOGY OF THE CONDUCTED STUDIES}

The methodical layer of analyses was based on the theory of probability, and more precisely on probit models. They allowed the evaluation of the statistical significance and chances of the occurrence of the considered innovative phenomena due to particular phases of the business cycle. The probit regression allowed the precise estimation of the parameter value with the determination of their significance for the dependant variables expressed in binary. Such method gives satisfactory and stable results in case of a large and static sample of companies, in which the dependant variable takes the quality form, when it is difficult to present changes in time within the studies phenomena.

All variables adopted for testing - dependent and independent - have binary character, meaning they reach values 0 or 1 . As a result of this, the interpretation of the achieved test results was conducted based on the structural form of the model, achieved probability results and necessary statistics (standard errors, t-student's statistics, Chi-square statistics, probability of the model's significance). A positive sign appearing with the main parameter informs us that the probability of the occurrence of the event of the innovative character $(\mathrm{p} 1)$ is statistically significantly higher in the specified group of industrial subjects towards the rest of the community. The negative sign (p2) is interpreted opposite. Probit type of modelling constitutes an extremely effective research tool, what has been confirmed with its many usages by the test authors in many regions in the country.

The study used a number of independent variables: the size of economic entities (divided according to: micro, small, medium and large enterprises). Dependent variables in this case are mostly: 
a) size of expenditures on the innovation activity in relation to their structure ${ }^{1}$,

b) implementation of new processes and products taking into account specific solutions (new technological processes and new products),

c) subjective approach of the innovation cooperation ${ }^{2}$.

As mentioned above, some methodical analysis was based on probability theory. While several of the seventeen dependent variables were:

a) the occurrence in industrial investment in innovation activities, but in relation to their structure, namely the R \& D, investments in new machinery and equipment, as well as buildings, structures, land and investment in new computer programs

$$
y_{i}=\left\{\begin{array}{l}
0 \text { if the inputs have not occurred } \\
1 \text { if the inputs have occurred }
\end{array}\right.
$$

b) implementation of new processes and products, taking account of specific solutions in this field and, therefore, new products and new processes,

$$
y_{i}=\left\{\begin{array}{l}
01 \text { if the solution have not been deployed } \\
1 \text { if the solution have been deployed }
\end{array}\right.
$$

c) cooperation in the field of innovation in terms of subjective, that is, suppliers, competitors and customers, as well as universities, $\mathrm{R} \& \mathrm{D} \mathrm{s}$ and foreign research institutes.

$$
y_{i}=\left\{\begin{array}{l}
0 \text { if there wasn't a cooperative relationship } \\
1 \text { if there was a cooperative relationship }
\end{array}\right.
$$

The study used a number of independent variables: the size of economic entities (divided according to: micro, small, medium and large enterprises). Adopted a set of independent variables are the reference planes, which reflect the activity of industrial enterprises, adopted on the basis of the methodology commonly used in OECD countries (Oslo Manual 2005).

Models were generated using the Statistica program, which in authors opinion and own experience is the most popular software used while doing econometric analyzes. Authors have been working with this software for 8 years now. Previously all data were prepared for calculations in the Excel spreadsheet.

1 The study included research and development, investments in new machines and technical equipment, investments in buildings and structures, and lands or new software.

2 Analyses include the innovation cooperation in the subjective approach with suppliers, recipients, competitors, universities, JBR and foreign research institutes. 


\section{THE INFLUENCE OF THE BUSINESS CYCLE ON THE INNOVATION ACTIVITY OF ENTERPRISES IN MAZOWIECKIE PROVINCE}

\section{First situation - prosperity}

In the analyses periods, 351 industrial enterprises declared that they were in the recession period (52\%), so this is the dominant group. Subjecting the group of enterprises declaring the prosperity to the probit modelling there were obtained interesting and uniform study results. For all analysed areas of innovation there were obtained statistically important parameters with the positive sign, without exception. This means that industrial enterprises are statistically more often likely to undertake each of the analyses innovation activities in the recovery phase than in other phases of the business cycle. These positive dependencies can be noticed both for the financial expenditures incurred on studies and development, implementation of new technological processes, and the innovation cooperation. Thus, the obtained study results confirm the sense of support of this group of subjects using various instruments of the innovation policy either on the domestic or regional level. Moreover, on this stage of considerations, doubts are brought by the hypothesis about the anti-cyclical innovation activity of enterprises of the national industrial system in Poland.

Table 1

The value of the parameter with the independent variable "recovery", in probit models describing the innovations of the industrial system in Mazowieckie province

\begin{tabular}{|l|c|c|c|c|c|c|c|}
\hline \multicolumn{1}{|c|}{ Attribute of innovation } & Parameter & Standard error & $\begin{array}{c}\text { Statistics of } \\
\text { t-student }\end{array}$ & $\chi^{2}$ & $\mathrm{P}>|\mathrm{z}|$ & $\mathrm{p}_{1}$ & $\mathrm{p}_{2}$ \\
\hline Expenditures on B+R activity & $+0,61$ & 0,10 & 6,04 & 37,23 & 0,00 & 0,46 & 0,24 \\
\hline $\begin{array}{l}\text { Investments in the so far non- } \\
\text { applied (including): }\end{array}$ & $+0,52$ & 0,11 & 4,97 & 25,07 & 0,00 & 0,81 & 0,64 \\
\hline $\begin{array}{c}\text { a) in buildings, premises and } \\
\text { lands }\end{array}$ & $+0,26$ & 0,11 & 2,42 & 5,87 & 0,02 & 0,27 & 0,19 \\
\hline $\begin{array}{c}\text { b) in machines and technical } \\
\text { equipment }\end{array}$ & $+0,44$ & 0,10 & 4,42 & 19,67 & 0,00 & 0,72 & 0,56 \\
\hline Software & $+0,37$ & 0,10 & 3,70 & 13,76 & 0,00 & 0,68 & 0,54 \\
\hline Implementation of new products & $+0,31$ & 0,10 & 3,13 & 9,85 & 0,00 & 0,70 & 0,59 \\
\hline $\begin{array}{l}\text { Implementation of new techno- } \\
\text { logical processes (including): }\end{array}$ & $+0,43$ & 0,10 & 4,20 & 17,77 & 0,00 & 0,75 & 0,60 \\
\hline a) by-production systems & $+0,43$ & 0,10 & 4,18 & 17,63 & 0,00 & 0,38 & 0,24 \\
\hline b) support systems & $+0,25$ & 0,11 & 2,27 & 5,21 & 0,02 & 0,23 & 0,16 \\
\hline Cooperation with suppliers & $+0,22$ & 0,11 & 2,05 & 4,23 & 0,04 & 0,28 & 0,21 \\
\hline Cooperation with universities & $+0,55$ & 0,21 & 2,65 & 7,85 & 0,01 & 0,05 & 0,02 \\
\hline Cooperation with national JBR & $+0,29$ & 0,14 & 2,03 & 4,18 & 0,04 & 0,11 & 0,06 \\
\hline Innovation cooperation, total & $+0,27$ & 0,10 & 2,73 & 7,45 & 0,01 & 0,48 & 0,37 \\
\hline
\end{tabular}

where:

Statistics of t-student - the exact results have been copied from the Statistica software - rounded to two decimal places.

$\chi^{2}-$ Chi-square compliance test,

$\mathrm{P}$ - probability of the model's irrelevance

$\mathrm{P}_{1}$ - probability of the occurrence of the given phenomena in the examined group of enterprises,

$\mathrm{P}_{2}$ - probability of the occurrence of the given phenomena in other groups of enterprises.

Source: own study based on research evidence. 
Examining in detail the values of probabilities, however, we notice several other interesting regularities. Firstly, there is a wide variation between the mathematical value of chances in the areas of financing and implementation, and the innovation cooperation. Enterprises found in the period of recovery, despite the fact that they more often than other subjects finance and implement new solutions, they are still less often interested in entering the relations of cooperation, mostly horizontal. High values of probability are obtained for investments in fixed assets $(0,81)$, including the purchase of machines and equipment $(0,72)$ and computer software $(0,68)$, implementation of new products $(0,70)$ and technological processes $(0,75)$, with special emphasis on new production methods $(0,38)$.

In the area of innovation cooperation the subjects are more often interested in the vertical links - with suppliers $(0,28)$, when the horizontal ones occur very rarely due to the considered subject of cooperation.

In summary, enterprises in the prosperity period are significantly more likely to accomplish various forms of innovation activity, mostly in the area of $\mathrm{B}+\mathrm{R}$ works, investment in fixed assets, implementation of new products and technological processes in manufacturing processes or the vertical innovation cooperation. However, not all areas should be potentially supported by various mechanisms of the innovation policy. This mostly results from the fact of achieving the probability values much above the average (certainty of events). In this situation you should consider the meaning of supporting the enterprises, which regardless of the occurrence of innovation policy instruments, will accomplish various forms of the innovation activity (displacement of efficiently operating market mechanisms). Thus, the directions of stimulation in the recovery period should oscillate around the following activities: $\mathrm{B}+\mathrm{R}$ activity, investment in new buildings, implementation of new products and methods of their manufacturing, innovation cooperation along the supply chain. In case of others, we will deal with 1) the situation of the displacement from the market by the state policy (high probability values), and 2) with non-system attempts to stimulate the innovation activity - high costs and its low efficiency (low probability values).

\section{Second situation - recession}

In the analysed period, 162 industrial companies declared that they were in the period of recession (24\%). They constituted the relatively low percentage of the analysed group of subjects, and also taking into account the occurrence during thee duration of analyses of mostly favourable tendencies in the economy, the obtained information can be considered reliable.

As expected, since the period of prosperity has positively and systemically influenced the innovation processes, the recession time is responsible for the opposite phenomenon. This time, out of eighteen potential econometric models in eight the parameters and models as a whole achieved the statistical significance. The lack of important dependencies was noted for the investments, the buildings and structures, and software, within implementation - of new products and methods of producing and the supporting systems, while for the innovation cooperation - cooperation with recipients, PAN units, foreign JBR, universities, what means that the indicated activity decreases significantly during the slowdown. In other cases all parameters achieved the negative sign, and thus the period of recession has systemically and negatively influence the innovation behaviours of the studied enterprises. 
Table 2

The value of the parameter with the independent variable "slowdown", in probit models describing innovations of the industrial system in Mazowieckie province

\begin{tabular}{|c|c|c|c|c|c|c|c|}
\hline Attribute of innovation & Parameter & Standard error & $\begin{array}{l}\text { Statistics of } \\
\text { t-student }\end{array}$ & $\chi^{2}$ & $\mathrm{P}>|\mathrm{z}|$ & p1 & $\mathrm{p} 2$ \\
\hline Expenditures on $\mathrm{B}+\mathrm{R}$ activity & $-0,58$ & 0,13 & $-4,65$ & 22,63 & 0,00 & 0,20 & 0,40 \\
\hline $\begin{array}{l}\text { Investments in the so far non-applied } \\
\text { (including): }\end{array}$ & $-0,32$ & 0,12 & $-2,75$ & 7,49 & 0,01 & 0,64 & 0,75 \\
\hline a) in machines and technical equipment & $-0,33$ & 0,11 & $-2,90$ & 8,41 & 0,00 & 0,55 & 0,68 \\
\hline Software & $-0,33$ & 0,11 & $-2,94$ & 8,65 & 0,00 & 0,52 & 0,65 \\
\hline $\begin{array}{l}\text { Implementation of new technological } \\
\text { processes (including): }\end{array}$ & $-0,34$ & 0,12 & $-2,97$ & 8,79 & 0,00 & 0,58 & 0,71 \\
\hline a) by-production systems & $-0,55$ & 0,13 & $-4,27$ & 19,18 & 0,00 & 0,18 & 0,36 \\
\hline Cooperation with suppliers & $-0,25$ & 0,13 & $-1,97$ & 3,98 & 0,05 & 0,19 & 0,27 \\
\hline Cooperation with national JBR & $-0,50$ & 0,20 & $-2,53$ & 7,31 & 0,01 & 0,04 & 0,10 \\
\hline
\end{tabular}

where:

$\chi^{2}-$ Chi-square compliance test,

$\mathrm{P}$ - probability of the model's irrelevance

$\mathrm{P}_{1}$ - probability of the occurrence of the given phenomena in the examined group of enterprises,

$\mathrm{P}_{2}$ - probability of the occurrence of the given phenomena in other groups of enterprises.

\section{Source: own study based on research evidence.}

Analysing the reached probability values we once again can see their strong internal differentiation. However, there are none, which take very high values, as it happened in the recovery phase (with the exception of investments in fixed assets - the value of probability on the level of 0,64). Despite the slowdown period, the enterprises interested in financing (beyond the B+R works and investments in new buildings) and implementation of new products and technologies. Chances for such phenomena are closed in the range of 52\%-64\%. However, in case of the implementation of new technological processes, the implementation of by-production systems shows relatively low probability $(0,18)$.

The making of the innovation cooperation takes place in the recession periods much more rarely. Its largest chances are again observed on case of the vertical connection in the supply chain - with suppliers (after 19\%), what still significantly differs from the phenomena of financing and implementation of new solutions. In the second case - cooperation with the national JBR - probability oscillates around zero.

Summing up, the support in the recession phase with mechanisms of the "visible hand" (innovation policy) in Poland should concern a small number of areas. Especially susceptible to acceleration are the investments in new machines and technical equipment $(0,55)$, purchase of software $(0,52)$, implementation of new technological processes $(0,58)$. Others achieve low or very low probability values and attempts of their support will have the marks of non-system, isolated and separated actions without the influence on industry as a whole.

\section{Third situation - stagnation}

In $23,8 \%$ of the studied cases it was declared that the companies are in the stagnation phase with nonchanging incomes in the analysed period (161 companies), so it is almost identical group of enterprises, like those found in the recession situation. Since in the recovery and recession phase we met the polarising 
approach to the accomplishment of innovation processes, it was expected that the stagnation phase will become the bridge connecting the listed opposite phases of the business cycle.

Table 3

The value of the parameter with the independent variable "stagnation", in probit models describing innovation of the industrial system in Mazowieckie province

\begin{tabular}{|l|c|c|c|c|c|c|c|}
\hline \multicolumn{1}{|c|}{ Attribute of innovation } & Parameter & Standard error & $\begin{array}{c}\text { Statistics of } \\
\text { t-student }\end{array}$ & $\chi^{2}$ & $\mathrm{P}>|\mathrm{z}|$ & $\mathrm{p}_{1}$ & $\mathrm{p}_{2}$ \\
\hline Expenditures on B+R & $-0,30$ & 0,12 & $-2,49$ & 6,29 & 0,01 & 0,27 & 0,38 \\
\hline $\begin{array}{l}\text { Investments in so far non-applied } \\
\text { (including): }\end{array}$ & $-0,33$ & 0,12 & $-2,81$ & 7,81 & 0,01 & 0,64 & 0,75 \\
\hline a) in buildings, premises and lands & $-0,36$ & 0,13 & $-2,71$ & 7,62 & 0,01 & 0,16 & 0,26 \\
\hline b) in machines and technical equipment & $-0,23$ & 0,11 & $-2,05$ & 4,17 & 0,04 & 0,58 & 0,67 \\
\hline New production methods & $-0,23$ & 0,11 & $-2,00$ & 4,01 & 0,05 & 0,37 & 0,46 \\
\hline Cooperation with universities & $-0,80$ & 0,37 & $-2,19$ & 7,29 & 0,01 & 0,00 & 0,04 \\
\hline
\end{tabular}

where:

$\chi^{2}-$ Chi-square compliance test,

$\mathrm{P}$ - probability of the model's irrelevance

$\mathrm{P}_{1}$ - probability of the occurrence of the given phenomena in the examined group of enterprises,

$\mathrm{P}_{2}$ - probability of the occurrence of the given phenomena in other groups of enterprises.

Source: own study based on research evidence.

But it did not happen. It turned out that it was estimated that, just like in case of the "slowdown" variable, six models with parameters which were statistically significant. The only change concerned the innovation cooperation and it consisted of the lack of model for the cooperation with suppliers and national JBR, and the appearance of universities. However, what is the most important, is the fact that in all models parameters achieved negative values. Thus, the stagnation phase has a systemic effect on the inhibition of innovation processes in Polish enterprises. Moreover, the power of this negative impact, taking into account the achieved probability values, is similar to the one from the recession period, and sometimes it is even higher.

Potential directions of support of the innovation activity should concern the investment in new machines and technical equipment $(0,58)$, implementation of methods of their production $(0,37)$. The chance for the innovation cooperation achieved the value on the zero level. This does not change the fact that they do not have chances to the system innovation dynamism of the industry while undertaking the attempts of their stimulation.

\section{CONCLUSIONS}

The results of the conducted studies show that the period of economic acceleration favors the system acceleration of the technological progress of the Polish industry and fundamentally on this stage of its development it should be supported by the instruments of the innovation policy, however not in every area. Support instruments should be directed at the B+R activity, investments in new buildings, implementation of new products and methods of their production, and innovation cooperation along the supply chain. Such "intelligent" stimulation should accelerate the technological changes in the industry, what in turn will contribute to the system, high and self-sustaining auto-dynamism in Poland. 
In turn, acceleration of innovation processes using the policy instruments in the recession period should be done with great care and focus of efforts on the narrow and prognosticating the systemic impact of a group of areas, according to the concept of "intelligent specializations". In this case we should pay special attention to and support enterprises with regard to investments in new machines and technical equipment, purchase of software and implementation of new technological processes.

Finally, at the end, the phase of stagnation, which has a systemic and negative influence on the accomplishment of innovation processes in the Polish industry, like in the recession period. Thus, enterprises are more interested in the limitation of the risk connected with this activity than the attempt to anticipate the market events. Entrepreneurs themselves take the waiting and conservative position. In this case the instruments of the innovation policy should support the investments in new machines and technical equipment and implementation of new production methods.

Taking into the account the fact that the Polish economy is slowly emerging from the phase of stagnation, we shouldn't expect in the near future the high innovation dynamism. This does not change the fact that despite the unfavorable market conditions, there exist areas of potential directions of support of the discussed innovation activity of industrial enterprises in Mazowieckie province.

\section{REFERENCES}

Aghion P., Saint-Paul G. (1998), Uncovering some causal relationships between productivity growth and the structure of economic fluctuations: A tentative survey. "Labour", vol. 12(2), pp. 279-303.

Archibugi D., Filippetti A., Frenz M. (2013), The impact of the economic crisis on innovation: Evidence from Europe, "Technological Forecasting \& Social Change”, Vol. 80, Issue 7, pp. 1247- 1260.

Canton E., Uhlig H. (1999), Growth and the cycle: Creative destruction versus entrenchment, "Journal of Economics", Vol. 69, No. 3, pp. 239-266.

Clark J., Freeman C., Soete L. (1981), Long waves, inventions, and innovations, "Futures”, No. 13(4), pp. 308-322.

D’Estea P., Iammarinob S., Savonac M., von Tunzelmannc N. (2012), What hampers innovation? Revealed barriers versus deterring barriers, "Research Policy", Vol. 41, Issue 2, pp. 482-488.

Dominiak J., Churski P. (2012), Rola innowacji w ksztattowaniu regionów wzrostu i stagnacji gospodarczej w Polsce, „Studia Regionalne i Lokalne”, vol. 4, pp. 54-77.

Etzkowitz H., Leydesdorff L. (2000), The dynamics of innovation: from National Systems and "Mode 2" to a Triple Helix of university-industry-government relations, "Research Policy", No. 29, pp. 109-123.

Francois P., Lloyd-Ellis H. (2003), Animal Spirits through Creative Destruction, "The American Economic Review", Vol. 93, No. 3, pp. 530-550.

JRC: Cincera M., Cozza C., Tübke A., Voigt P. (2010), Doing R\&D or not, that is the question (in a crisis...), IPTS working paper on corporate R\&D and Innovation, Vol. 12.

KE: Innovation Union Scoreboard 2013. http://ec.europa.eu (referred on 26/09/2013).

Maddala G.S. (2006), Ekonometria, Wydawnictwo Naukowe PWN.

Madrid-Guijarro A., García-Pérez-de-Lema D., Van Auken H. (2013), An Investigation of Spanish SME Innovation during Different Economic Conditions, "Journal of Small Business Management”, Vol. 51, Issue 4, pp. 578-601.

OECD (2005), Oslo Manual, Third edition, Paris.

Schumpeter J. (1939), Business Cycle. A Theoretical, Historical and Statistical Analysis of the Capitalist Process, McGrawHill Book Company, New York Toronto London.

Shleiffer A. (1986), Implementation Cycles, “The Journal of Political Economy”, Vol. 94, No. 6, pp. 1163-1190. 
Soete L. (2009), Challenges for making European research an engine of competitiveness, Presented at VINNOVA workshop: How can a future ERA support and stimulate research, innovation, and sustainable economic growth in Europe? Berlin, March 17th.

Stanisz A. (2007), Przystępny kurs statystki. Tom 2, Statsoft, Kraków.

Stiglitz J. (1993), Endogenous Growth and Cycles, NBER WP N4286.

Welfe A. (1988), Ekonometria, PWE, Warszawa. 